\title{
Faculty Perspectives on Student Attendance in Undergraduate Medical Education [Corrigendum]
}

Campbell AM, Ikonne US, Whelihan KE, Lewis JH. $A d v$ Med Educ Pract. 2019;10:759-768.

Page 761, Faculty perspectives about professionalism, job satisfaction, and active learning section, fourth sentence, the text "Ten disagreed that students who regularly attended large-group sessions had better academic performance" should read "Ten agreed that students who regu- larly attended large-group sessions had better academic performance".

Table 3 on page 763, the values in the Students who attend large group sessions regularly have better academic performance and Active-learning sessions are more effective with higher attendance rows are incorrect. The correct Table 3 is as follows.

Table 3 Faculty Perspectives About Student Attendance, Active Learning, and Job Satisfaction ( $\mathrm{N}=26)$

\begin{tabular}{|c|c|c|c|c|c|}
\hline \multirow[t]{2}{*}{ Survey Question } & \multicolumn{5}{|l|}{ No. (\%) } \\
\hline & Strongly Disagree & Disagree & Neutral & Agree & Strongly Agree \\
\hline $\begin{array}{l}\text { Student attendance at non-mandatory large group session } \\
\text { indicates their level of professionalism }\end{array}$ & $10(38)$ & $5(19)$ & $5(19)$ & $5(19)$ & I (4) \\
\hline $\begin{array}{l}\text { I feel more job satisfaction with higher attendance at large group } \\
\text { sessions }\end{array}$ & $2(8)$ & $2(8)$ & $3(12)$ & $12(46)$ & $7(27)$ \\
\hline $\begin{array}{l}\text { I prefer to incorporate active learning in my large group sessions } \\
\text { when attendance is mandatory }\end{array}$ & I (4) & I (4) & $9(35)$ & $12(46)$ & $3(12)$ \\
\hline $\begin{array}{l}\text { Students who attend large group sessions regularly have better } \\
\text { academic performance }\end{array}$ & $6(23)$ & $2(8)$ & $8(31)$ & $10(38)$ & $0(0)$ \\
\hline $\begin{array}{l}\text { Lecture capture is an effective alternative to large group } \\
\text { attendance }\end{array}$ & $3(12)$ & $3(12)$ & $8(31)$ & $7(27)$ & $5(19)$ \\
\hline $\begin{array}{l}\text { Lecture capture should not be used as a substitute for attending large } \\
\text { group sessions }\end{array}$ & $6(23)$ & $6(23)$ & $8(31)$ & $2(8)$ & $4(15)$ \\
\hline Lectures are more effective with higher attendance & $5(19)$ & $4(15)$ & $6(23)$ & $8(31)$ & $3(12)$ \\
\hline $\begin{array}{l}\text { Active-learning sessions are more effective with higher } \\
\text { attendance }\end{array}$ & $2(8)$ & I (4) & 7 (27) & II (42) & $5(19)$ \\
\hline $\begin{array}{l}\text { I prefer that all large group sessions have mandatory } \\
\text { attendance }\end{array}$ & II (42) & $4(15)$ & $8(3 I)$ & I (4) & $2(8)$ \\
\hline $\begin{array}{l}\text { I prefer that all large group sessions with an active-learning } \\
\text { component have mandatory attendance }\end{array}$ & $5(19)$ & $3(12)$ & $5(19)$ & $8(3 I)$ & $5(19)$ \\
\hline
\end{tabular}

The authors apologize for these errors and advise they do not affect the scientific conclusions of the paper. 


\section{Publish your work in this journal}

Advances in Medical Education and Practice is an international, peerreviewed, open access journal that aims to present and publish research on Medical Education covering medical, dental, nursing and allied health care professional education. The journal covers undergraduate education, postgraduate training and continuing medical education including emerging trends and innovative models linking education, research, and health care services. The manuscript management system is completely online and includes a very quick and fair peer-review system. Visit http://www.dovepress.com/testimonials.php to read real quotes from published authors.

Submit your manuscript here: http://www.dovepress.com/advances-in-medical-education-and-practice-journa 